\title{
Gender and Police Leadership: An Analysis of Metropolitan Police Departments in South Africa
}

\author{
Dee Khosa*
}

\author{
Tshwane University of Technology, Aubrey Matlala Street, Soshanguve, Pretoria, South Africa
}

\begin{abstract}
Despite a number of initiatives aimed at improving the representation and progressive of women in the law enforcement. Studies continue to document the persistence of gender inequality within law enforcement agencies all over the world and South Africa is not an exception. This article bring to light gender inequalities in the law enforcement sector where women in leadership ranks remains low. Historically, the police career was male-dominated and females were not allowed to work in the police. Therefore, equal gender representation in the workplace should by now be at an advanced developmental stage in South Africa since the abolition of discrimination rules. The Commission on Employment Equity of South Africa reported that women comprised $44.8 \%$ of the economically active population, yet males were still in charge of senior management positions in South African industries including the law enforcement environment. The data was collected from female officers from Metropolitan Police departments in Gauteng province. The findings suggest that culture, stereotypes, economic and socio-political dynamics, and physical fitness were perceived as barriers that hindered the representation of women into senior leadership positions.
\end{abstract}

Keywords: Leadership, women in leadership, gender equality, Metropolitan police department.

\section{INTRODUCTION}

There is a wealth of research investigating the impact of women in the leadership role (Gipson, Pfaff, Mendelsohn, \& Burke, 2017). Gender-based discrimination is still evidenced in various workplaces. Ernst \& Young Global Limited, (2011) and Statistics South Africa (2017) reported that there are 57.7 million people in South Africa and more than half of the population $(52 \%)$ is women according to home affairs registration, yet they are under-represented in social, political and economic spheres. Stereotype expectations have contributed to the ongoing discrimination, that is, the exclusion of women in maledominated sectors. Women have been and to a certain extent, still are part of a minority group in the law enforcement environment but the past decade has seen a steady infusion of females into this once male dominated occupation (Ayman, Korabik, \& Morris, 2009). This status quo is maintained in various ways, for example, many employers have argued that it is not feasible to appoint women in senior positions because they would not cope with the demands of the position. Women had previously been excluded from exercising any form of expressing influence in policing, but they are now taking their place in law enforcement, in spite of the objections of some of their male colleagues still prevailing. The government has initiated policies and programmes that promote the inclusion of women in all spheres of life. Despite these milestones, women continue to face systemic barriers that hinder their

*Address correspondence to this author at the Tshwane University of Technology, Aubrey Matlala Street, Soshanguve, Pretoria, South Africa;

Tel: +2712 382 9811; E-mail: khosad@tut.ac.za advancement in senior leadership positions in male dominated jobs. Whilst there are literatures on the unequal gender representation in historically patriarchal societies, there is strong consensus in the academic literature that diversity in leadership is beneficial to society, organisations and individuals (Shore, Randel, Chung, Dean, Ehrhart, \& Singh, 2011). There is less agreement on ways to assess impediments to diversity, specifically the inclusion strategies promoting women in South Africa's Metropolitan Police Departments (MPDs). Gender disparity exist in leadership positions within the police service, the absence of women among senior positions is more visible. According to Ernst \& Young (2000) emphasizes that societal structures should no longer be based on the conventional assumption that men are superior to women. One of the notable advancements in the debate has been the move to consider gender equality as a key element of development. Palmer (1991) mentions that women's concerns were first integrated into the development agenda in the 1970s as a response to a growing evidence that women that economic and social development efforts had not benefited women as much as men. This burgeoning state of societal awareness encourages gender equality and the rejection of other entrenched forms of inequality such as racism, homophobia, heterosexism, classism and diverse theories about the relationships between gender inequality and the environment, which is the root of gender oppression (Fall, 2015). It can be argued that the empowerment of women in Metropolitan Police Departments (MPD), requires full integration of the overlapping social roles women assume regardless of whether their work is seen as a job, career or profession; and, this integration should not only benefit 
sexual or domestic issues in the community, but should support the changing social life of the nation within public, commercial and industrial life. Discrimination of women has taken a variety of forms from marginalization to various form of mistreatment.

\section{HISTORICAL BACKGROUND OF WOMEN IN POLICING IN SOUTH AFRICA}

Cultures, socio-political issues and religion have in the past promoted patriarchy and the oppression of women (Attoh Franca, 2017). In South Africa, police services, such as the metropolitan police departments are now obliged to ensure participation of women in various policing structures, from community policing to strategic policing for community safety. Mlotshwa, (2017) reported that the obligation to diversify into leadership positions within law enforcement environment presented opportunities to improve the state of affairs in South Africa, especially with regards to women participation in leadership positions. Various South African leaders have advocated for women inclusion into various sectors specifically the male dominated industries. For example, in 1956, Sophia de Bruyn led the Women's March to the Union Buildings in South Africa, protesting against discrimination of women in society (South African History Online, 2017). She was the founder of the South African Congress of Trade Union (SACTU) which is known as Congress of South African Trade Union (COSATU). In 1955 Sophia was appointed as a full-time organiser of the 'Coloured People's Congress' in Johannesburg (Polisa, 2016) \& (South African History Online, 2017).

In 2016, Sophie de Bruyn addressed women and advocated for young generation to take initiative in the fight against inequality. She indicated that the government has a role to play, its government should also ensure that the 50-50 rule not only applies to political positions, but should also be seen in senior positions in the government (South African History Online, 2017). The revolution against gender inequality was very evident in the 19th century, many women had started challenging gender equality, by skipping rules and customs of the encroaching time (Newham, Masuku \& Dlamini, 2006) and (Gerson, 2009). Another example is a women named Concepcion Arenal who was the first woman to attend university in Spain (Newham, Masuku \& Dlamini, 2006). It is reported that in 1820 , to avoid detection she had to dress like men in order to be allowed to enrol as a student at the university to study law (Newham, Masuku \& Dlamini, 2006 \& Hlongwane, 2016)
First Entry of Women into Law Enforcement Environment

The initiation of policewomen and women patrols in South Africa was adopted from England by women during the course of the First World War (Watson, 1999:52). It is reported that this was due to the fact that the Commissioner of Police in Cape Town, Colonel Gray, supported the idea of policewomen to do patrol work (Watson, 1999). In 1916, the first woman was appointed in the position of 'Special Patrol. This happened when the Cape Town Council agreed to subsidise female employees, but, as a result of criticism and objections about white women patrolling Black and Coloured areas, the subsidy was revoked (Watson, 1999). This author stated that this retraction resulted in job applications from females wanting to join the police force being rescinded.

In 1916, the Women's Christian Temperance Union in Port Elizabeth tried to persuade the City Council to reinstate their employment policy to employ policewomen in the city (Watson, 1999). They were however unsuccessful in their proposal. The general consensus against women doing police work was that females are deemed unfit for this kind of work because of their gender and physique (Bezuidenhout \& Theron, 2000:22). In this regard, attempts were made again in 1919 to re-introduce women to the police department (Watson, 1999). This time, Watson (1999) reported that women were expected to perform detective work in Johannesburg in the field of immorality and child prostitution. In 1910, Colonel Gray in Cape Town police, who supported views on utilising women in the police service, promised to put the matter before the SAP Commissioner in Pretoria (Watson, 1999). In July 1929, however, the Justice Department stated that it did not consider conditions in South Africa suitable for the employment of women in the police service (Watson, 1999). Even though white women won the right to vote in 1931, their right to serve in the SAPS took much longer.

\section{Factors that Contribute to Women Participation in the Police}

There were several factors that contributed to women participation in the police. These factors included a shortage of manpower in the police and the increase of crime (South African Police, 2002). Moreover, organisations such as the National Women's Council of South Africa and the National Council for Child Welfare proposed that women be appointed as 
members of SAPS (South African Police, 2002). These proposals resulted in the first serious changes being implemented within the policing fraternity. The proposals were followed by investigations in the late sixties, with the aim of assessing the pros and cons of initiating women into policing (Van Kessel, 2001). All relevant departments of the SAP were asked for their inputs; consequently, in 1971 Minister Lourens Muller stated during the Police Budget Debate in Parliament that women wanting to join the SAP would be considered and that their appointment was nearly a forgone conclusion (De Witt Dippenaar, 1988:428). The Minister further stated that female employees would be given specific tasks that involved women as the accused or where women are involved as witnesses, specifically in cases where women are the complainants. Similarly, female employees would also be involved with programs aimed at the youth (De Witt Dippenaar, 1988: 428-429). However, despite these good intentions to advance of women in the MPD's, the suggested improvements remained to be a perception that women are deemed inferior to their male counterparts. In police studies, scholars have investigated gender differences, barriers, job satisfaction, and discrimination. (Drew, Carless, \& Thompson, 2008; Kurtz, Linnemann, \& Williams, (2012); Somvadee \& Morash, 2008). Marginalization is also the biggest hindrance for the majority of the female officers.

\section{POLICIES PROTECTING WOMEN CIVIL RIGTHS IN SOUTH AFRICA}

It is important to reiterate that there are several legislative framework empowering women or guiding against gender inequality in the republic of South Africa, such as paving the way for the establishment of institutions and entities that are charged with the responsibility of implementing the policies on gender equality. Over the past two decades (1994-2017), various pieces of legislation relating to gender equality have been promulgated. This has been accompanied by the establishment of various custodians of gender equality; examples include the Commission for Gender Equality (CGE) and the Ministry for Women, Children and People Living with Disabilities. Public institutions, parastatals and government entities are established on the basis of legislation. Hence, the institutions and entities responsible for the promotion of gender equality had to be preceded by the proclamation of relevant legislation. Section 8 of the Promotion of Equality and Prevention of Unfair Discrimination Act (PEPUDA) indicates that women in police and women in leadership positions are protected against inequality of access to opportunities within MPDs. The institutions and entities that were established for this purpose include the Commission for Gender Equality, Ministry of Women in the presidency, as well as the National Gender.

Women are increasingly participating in employment in South Africa (Stats SA, 2015). It is noted in the National Development Plan (NDP) that the inclusion of women in the main streams every spectrum of activities to be not only a catalyst to poverty reduction and elimination of inequality in the South African society but also in the realisation of the 2030 set targets (National Planning Commission, 2010).

\section{PROBLEM STATEMENT}

The Commission of Employment Equity in South Africa reported that women comprise $44.8 \%$ of the economically active population; however, males still dominate senior management positions in South African companies (Commission of Employment Equity, 2017). According South African Employment Equity Report (2017), women hold only $29.5 \%$ of toplevel management positions and $30.7 \%$ of senior management positions. These results show significantly lower statistics than the governmentmandated target of having $44.4 \%$ management positions filled by women. Chung and Sahgal (2007:351) argue that owing to the alleged lack of career planning by women, in contrast to their male counterparts, contributes to the poor advancement of women to senior management positions. It is also important to note that the value of organisational practices influence the criteria for advancement. The Employment Equity Act no. 55 of 1998 requires that some organisations collect report and track the representation of their designated groups, such as but not limited to women, previously disadvantaged groups, and people with disabilities at all occupational levels, including senior management (Cilliers \& Stone, 2005; Diversity Leads, 2012; Pandor, 2005). Addressing gender inequalities is important, (Ernst \& Young Global Limited, (2011) argued that unequal gender representation should be addressed in order for the country to fully leverage its potential

The underrepresentation of women in leadership positions in the MPD's continues to be a matter of some concern, particularly in a traditionally male dominated industry such as law enforcement. Dean, 
Heather, \& Henry, (2009) has revealed that women continue to face challenges in advancing into leadership positions. Role of women in leadership positions were tested in the relationship between managerial leadership styles and organizational effectiveness. Significant resources and efforts have however been devoted to the development of programs that exclusively promote diversity and inclusion in the workplace, but no such efforts exist that pertinently encourages gender equality amongst MPD leaders. Furthermore, when it comes to strategies concerning the advancement of women in leadership positions, it is difficult if not impossible to get hold of tangible results or evidence of equal gender representation among leaders' operative within the MPD. There seems to be substantial gaps this sector: MPD has not progressed on diversity when compared with the South African Police Service (SAPS) and the private sector that have made serious inroads.

\section{THEORITICAL PERSPECTIVE}

\section{Women and the Glass Ceiling}

"Glass ceiling" is a concept from the 1980s describing an invisible barrier that blocks the access of women to the top - they can see where they want to get to, they can see their male peers going through (Singh, 2007). According to global trends of working women, the issues of the role of women in management and glass ceiling at work have been increasingly discussed (Rishani, Mallah, Houssami \& Ismail, 2015). Inequalities between men and women beside all activities and efforts cannot be eliminated. Hoobler, Lemmon, \& Wayne, (2016) is of an opinion that the invisible barrier exists as a result of discrimination of women in the workplace. Women and men differ, both in terms of the jobs in which they work and in their responsibilities, but over time, women's skills have become more similar to men's. Women have managed to break through the glass ceiling through goal-setting, self-assertion and self-promotion and directive communication, determination to persevere and achieve goals, and the need to be receptive to research and education that will advance a woman's career path (Baumgartner \& Schneider, 2010).

Women empowerment entails a process of change in which patriarchal relations are challenged so that men's traditional complimentary package of resources and services provided to ensure that goals are met. The United States Glass Ceiling Commission (1995) is of the view that discrimination can be direct when women are simply treated less favourably than men. Or it may be due to a policy or practice that, although not designed to discriminate, results in unequal treatment between men and women. Both types of discrimination are prohibited under organisation policies, but are unfortunately still present in some workplaces. Arfken, Bellar and Helms (2015:52) discusses the 'glass ceiling' phenomenon; it highlights gender prejudice, resulting in the exclusion of women from historically male-dominated positions. Christofides, Polycarpou, \& Vrachimis, (2013:87) states that in theory, nothing prevents women from rising as high as men. But in practice there is invisible but real barrier through which the next stage or level of advancement can be seen, but cannot be reached by qualified and deserving women. Glass ceiling is the specific type of gender inequality, not suggesting that is more unjust or larger than other types of inequality, just that is merely different and that is why it deserves distinction from other types of inequalities (Van der Berg, 2014).

The notion of gender equality is crucial for enhancing women's success. Equally promoting advancement to leadership positions to all workers regardless of gender can help the organization improve its performance. Pathak and Purkayastha (2016) argue that gender diversity management has a positive impact on organizational performance because having both male and female executives lead to better quality discussions.

\section{RESEARCH METHODOLOGY AND DESIGN}

This study adopted qualitative research approach, which enables the understanding of the phenomenon of gender inequality in the Metropolitan Departments (MPD's) in Gauteng Province of South Africa'.

\section{Population}

The population was approximately 3121 metropolitan police officers who work in various positions within the Metropolitan Police Departments (MPDs) in Gauteng province, South Africa. These police officers held positions such as executives, management and ordinary employees.

\section{Sampling}

Purposive sample technique was used to select senior and middle management officials from MPDs. Purposeful sampling allows the researcher to select people or events because they are interested, relevant 
and suitable for the research (Payne \& Payne, 2015). The duration of tenure, gender and position held in MPD were participation criteria used. In this case, the participants were 25 women who held their position for at least 5 and more years. All participants were from Gauteng province, in Ekurhuleni, Tshwane and Johannesburg MPDs. Participant representation from MPDs were as follows: 11 Tshwane, 9 Johannesburg and 5 Ekurhuleni.

\section{Data Collection Instrument}

Individual interviews were used to collect data. The interview responses were voice recorded. The aim of using individual interviews was to gather in-depth, qualitative data (Leedy \& Ormrod, 2005) from participants.

\section{Ethics Issues}

Ethics in research is a set of moral principles that are suggested by an individual or group (Goldsmith \& Lewis, 2000:57). Ethics in research refers to what is accepted or not acceptable when conducting a study (Resnik, 2011). The study has obtained ethical approval from the university's ethics committee, Ekurhuleni, Tshwane and Johannesburg MPDs. Participants signed informed consent forms, in line with ethics guide set by the University of South Africa code of ethics (UNISA, 2016). Interviews were voluntary, anonymity ensured, and no incentives provided.

\section{Data Analyses}

Henning, Van Rensburg, \& Smit, (2004:127) state that the aim of data analysis is to understand the relationship between concepts, constructs or variables as well as identify and classify whatever patterns might emerge in order to create themes in the data. In qualitative data analysis it is pointed out that data is transcribe from various form of collected data such as the transcribe data from interviews that are typed into word processing document. This means that interview questions asked to the participants were transcribed by the researcher. The qualitative analysis was done with the assistance from the professional qualitative data analyst using Atlas.ti ${ }^{\mathrm{TM}}$.

This study used the thematic analysis method to search for patterns that emerged from the interviews conducted with the participants. Thematic analysis entails assigning codes to patterned responses, and the prevalence of a code across data creates a theme (Saldana, s.a.; Ryan \& Bernard, 2000). Similarities and differences exist between thematic analysis and content analysis methods. The two methods are similar in that they generate themes from transcripts and interviews (Ryan \& Bernard, 2000). The two methods differ in that content analysis tends to quantify themes more than thematic analysis; meaning that qualitative data are often converted into numeric data or themes are reported as frequencies (Ryan \& Bernard, 2000). Coding in this study was conducted using Atlas. $\mathrm{ti}^{\mathrm{TM}}$ software.

\section{RESULTS AND DISCUSSION}

\section{Representation of Women in Senior Leadership Positions}

With regards to representation of women in senior leadership positions in MPDs, it is noted that various reasons were found in this study that prevented women to be in leadership position. Issues such as culture, stereotype and physical fitness were reported. It may be observed from the findings that culture had a negative impact on the appointment of women in leadership position. This is reported in literature McDowell (2016) that most companies and industries including the law enforcement industry before the democratic era, the management positions were occupied by males only. Another example to support the statement above is the observation in rural municipalities of South Africa where the chiefs, who are perceived to be the custodians of culture, play a role in leadership at the local government sphere (Khan, Lootvoet \& Mantzaris, 2006). The cultural dynamics in MPDs had negative impact, because it deprives women the opportunity to be in the leadership position.

It is noted from the findings that the problem with recruiting women in leadership position is stereotype with males in the work place. Men in MPD believed that there are certain tasks they should perform that women cannot perform. Kurtz, Linnemann and Williams, (2012) argued that globally, the police career was regarded as central to males, women were not allowed to participate in the police force. As law enforcement is a male-dominated profession gender stereotypes hamstring the professions ability to recruit and retain talented women. Gossett and Williams (1998) argue that women officers have made very slow progress toward full integration in policing due to barriers such as the attitudes of male officers. In contrast to this belief, (Mello \& Phago, 2007) argue that women are as intelligent and competent as men. Therefore, with change in time this stereotype has to come to an end, the police work should not be viewed as the men's job. 
Findings revealed that physical fitness is problem to recruiting women in senior leadership position in MPDs as it is one of the important factors. In this case, the recruitment process becomes a challenge for women. In this regard, Morash \& Haar (1995) argue that male officers are not eager to appoint women officers because of the masculine-oriented police subculture. (Dodge, Coie \& Lynam, 2011) asserted that the challenge of integrating women officers into the SWAT sub-culture requires change in perceptions of the overall culture that continued to endorse the values of masculinity.

\section{Advancement of Women}

Findings shows that passion, hard work, determination and education were the decision that made the women to have eager to advance to senior leadership position. About being passionate it was found that women are passionate about the police industry hence they saw a need to advance themselves. With regard to education, it may be argued that it is regarded as an important factor to advance higher positions at workplace. Education was also viewed as the best ingredients for success. This view is supported in literature that in South Africa, education is a means to women's empowerment-(Convention on the Elimination of Discrimination against Women (CEDAW), 1998). Even though Huhman (2016) argue that female graduates are still under-represented, particularly in more senior positions in higher education institutions, but the number of women academics in South African has also escalated, and that higher education institutions has increased from $31 \%$ of the workforce to $46.2 \%$. It has been revealed that there are reasons why women are not given opportunities or do not apply for more senior positions in their workplaces, including that they tend to underestimate their own abilities to perform functions.

It was found in this study that various critical skills crucial in MPDs for women to acquire in order to advance to senior position. For example, management skills and communications skills were found to be most critical. In this case it was important for women to have good communication skills in order to be recruited in the senior leadership position. It may be observed from the results that advice from other women in MPDs assisted them to focus when they join MPD.

\section{Lack of Effectiveness in Policies and Procedures}

It was found in this study that various policies and procedures are not implemented in the MPDs. This means the MPD's have the policies and procedures in place but do not adhere to their own legislative framework. In this regard, the MPDs should adopt the Kohlberg's stage of moral development theoretical framework (Lewis, Palacious \& Valenzuela, 2016). The aim should be to use the framework to assist in understanding and practicing the rights, obligations, duties and the importance of principles of conduct, rules as well as formal standards of judgment to be applied at work (Shields, Funk \& Bredemeier, 2016 ). It was found in this study that level 2 conventional level of Kohlberg's stage of moral development emphasis on conformity and stereotypical behaviour as well as authority, rules, and social order which impacts on the representation of women in work place as well as leadership position in the MPDs.

The findings revealed that recruiting women into senior management positions as problematic in MPDs. In this regard, it was found that equity is not practiced within MPDs. This is also stated by the United Nations Millennium Development Goals, goal 3 to promote gender equality and women empowerment (Ford, 2015; UNDP, 2015). South Africa battles to achieve equality targets because of other socio-economic affairs where women continue to have a higher rate of unemployment than men. Schwanke (2013) supports this argument and further indicates that women have not yet achieved equity in mid-management positions as it appears globally. It was also found in this study that women in MPDs were treated unfairly and discriminated against at work. In this regard, Section 8 of the Promotion of Equality and Prevention of Unfair Discrimination Act (Act 4 of 2000) prohibits unfair discrimination on the grounds of gender.

\section{Strategies in Place to Advance Gender Diversity}

The findings revealed that gender diversity and equity should be included in the MPDs strategies in order to fast-track the appointment of women in leadership position. Also, Act 4 of 2000 of the Promotion of Equality and Prevention of Unfair Discrimination Act states that women in police force and women in leadership position are protected against inequality of access and the opportunities that women should be given within the MPD. Though the policy is in place to address the equity in the work place, PercySmith (2000) argues that gender inequalities in nature and multi-dimensionality cannot be reduced to some single and universally agreed set of priorities.

It is noted from this study that MPD should provide training and development for women as one of the 
strategies to advance gender diversity in leadership within MPDs. In this instance, MPDs should create the career path for growth by introducing empowerment programme, workshops, training and seminars to build trust among male and female colleagues towards achievement of common goal. Findings from this research indicates that the recruitment strategy should be in place to balance the processes and procedures in MPDs. In this regard, MPDs should advertise leadership positions where women are given priority as articulated in the equity act 55 of 1988.

\section{RECOMMENDATIONS}

It is crucial that the MPDs adopt level 2 conventional level of Kohlberg's stage of moral development in order to have knowledge, understanding and practice the rights, obligations, duties and the importance of principles of conduct, rules as well as formal standards of judgment to be applied at work. This will assist in the transformation on conformity and stereotypical behaviour which impacts on the representation of women in work place in leadership position in the MPDs.

It is recommended that employment equity policies, training and development be incorporated in the strategies in MPD's and empowerment of women be practiced.

Another recommendation is mentorship and coaching to empower women to overcome fear of failure and rejection and learn that rejection and failure can be used as an opportunity to learn. When one learns from these experiences, it leverages strength and help address some development areas.

It is recommended that women are empowered to ensure that they are able to capitalize on the opportunities that are available so that the cycle of discrimination can be broken. When women are empowered, they can advocate for themselves and others.

It is crucial that the MPD's in South Africa as a whole to review their Human Resource practices and policies to ensure that it is creating a positive and constructive work environment for all employees. By doing this, the Departments can stand a good chance of attracting top talent as employers of choice who put the aspirations of their employees ahead.

Other Law Enforcement officers that did not fall within the scope of empirical survey can also use the findings to determine if they are adding any value to efforts to diversify the general labour in the country as a whole. In so doing, these departments can get closer to reality that will indicate if transformation need to be implemented in order to ensure that gender diversity is achieved across all Metropolitan Police Departments in South Africa.

\section{CONCLUDING THOUGHTS}

In conclusion, the new knowledge generated by this paper entails that there is a need for mechanisms of constructive feedback from managers to women in order to address shortfalls that affect women's advancement to leadership positions. Leadership development programmes must be tailored for women advancing to leadership positions so that they are coached or mentored on how to achieve employment goals. The proposed women's leadership development programme should have the elements necessary to tackle shortfalls in women's capacity to advance to leadership positions. The leadership development programme should be open to both men and women in order to address underlying ideologies or negative mind-sets regarding female leadership. MPDs should annually conduct research to identify barriers that impede women's advancement to leadership positions. MPD's should use the findings to design a leadership development programme tailored for women in order to address identified shortfalls, to resolve unequal gender representation in positions. Leadership development programmes tailored for women should be more than just semi-skills development programmes; they should incorporate all elements aligned to the concept of leadership.

In conclusion, the inclusion, representation, and participation of women into leadership positions should not be an afterthoughts or add-ons but expected considerations in policy design and implementation in MPD's should be adhered to. Finally, the MPD's must not shy away from developing and implementing measures to militate against the development and advancement of women.

\section{REFERENCES}

Arfken, D.E., Bellar, S.L. \& Helms, M.M. (2015). the ultimate glass ceiling revisited the presence of women on corporate boards Journal of Business Ethics, 50(2):177-186. https://doi.org/10.1023/B:BUSI.0000022125.95758.98

Attoh, Franca. (2017). Gender, religion and patriarchy: a sociological analysis of Catholicism and Pentecostalism in Nigeria. Advances in Social Sciences Research Journal 4. https://doi.org/10.14738/assri.414.3482 
Ayman, R., Korabik, K., \& Morris, S. (2009). Is transformational leadership always perceived as effective? Male subordinates' devaluation of female transformational leaders. Journal of Applied Social Psychology, 39.

https://doi.org/10.1111/j.1559-1816.2009.00463.x

Baumgartner, M. S., \& Schneider, D. E. (2010). Perceptions of Women in Management: A Thematic Analysis of Razing the Glass Ceiling. Journal of Career Development, 37(2), 559576.

https://doi.org/10.1177/0894845309352242

Bezuidenhout, C., \& Theron, A. (2000). Attitudes of male and female police officers towards the role of female police officers. Acta Criminologica: Southern African Journal of Criminology, 13 (3), 19-31. Available from: http//journals.co.za/content/crim/ [Accessed on 10/10/2020]

Christofides, L.N., Polycarpou, A. \& Vrachimis, K., (2013). Gender wage gaps, 'sticky floors' and 'glass ceilings', Labour Economics, Volume 21.

https://doi.org/10.1016/j.labeco.2013.01.003

Chung, S., \& Sahgal, P. (2007). Why do few women advance to leadership positions? Global Business Review, 8(2):351-365. https://doi.org/10.1177/097215090700800211

Cilliers F and Stone, K. (2005): Employment Equity Practices in three South African Information Technology Organisations. A Systems Psychodynamic Perspective. South African Journal of Industrial Psychology, 31(2): 49-57. Department of Industrial \& Organisational Psychology, UNISA. https://doi.org/10.4102/saijp.v31i2.193

Committee on the Elimination of Discrimination against Women (CEDAW). 1998. Committee on the Elimination of Discrimination against Women (CEDAW). Available from: http://www.ohchr.org/en/hrbodies/cedaw/pages/cedawindex. aspx [Accessed: 01/10/2020].

De Witt Dippenaar, M. (1988). The history of the South African police, 1913-1988. Silverton: Promedia

Dean, E. \& Heather, J. \& Henry, D. (2009). Challenges Women Face in Leadership Positions and Organizational Effectiveness: An Investigation. Journal of Leadership Education.

Diversity leads. (2012). women in senior leadership positions: Diversity institute. Ryrson University. Toronto

Dodge, K.A., Coie, J.D. \& Lynam, D. (2011). Aggression and antisocial behavior in youth. In Damon, W. \& Eisenberg, N. (eds.) 2011. Handbook of child psychology: Social, emotional, and personality development. New York, New York, United States of America: Wiley.

Drew, J., Carless, S.A., \& Thompson, B. M. (2008). Predicting turnover of police officers using the sixteen personality factor questionnaire. Journal of Criminal Justice, 36(1). https://doi.org/10.1016/j.jcrimjus.2008.06.003

Employment Equity Act. (1998). Available from: http:/www.acts.co.za/ emp_equity/index.htm. Accessed on 20/03/2020

Ernst \& Young Global Limited. (2011). Women of Africa: A powerful untapped economic force. Available from: http://www.ey.com/ZA/en/Business-environment/Women-ofAfrica--a-powerful-untapped-economic-force environment/Women-of-Africa--a- powerful-untappedeconomic-force [Accessed: 20/07/2020].

Fall, (2015). Women, gender, sexual studies. College of Humanities, University of Massachusetts Amherst,

Ford, L. (2015). Millennium development goal 3:15 achievement on gender equality. The Guardian. Retrieved from: https://www.theguardian.com/globaldevelopment/2015/jan/19 /sustainable-development-goals-united-nations. Accessed on 05/02/2019.

Gerson, K. (2009). The Unfinished Revolution: How a New Generation is Reshaping Family, Work, and Gender in America. Oxford University Press.
Gipson, Pfaff, Mendelsohn, \& Burke, (2017) Women and Leadership: Selection, Development, Leadership Style, and Performance. The Journal of Applied Behavioral Science. https://doi.org/10.1177/0021886316687247

Goldsmith, A., and Lewis, C. (2000). Civilian oversight of policing: Governance, democracy and human rights. Oxford: Hart Publishing.

Gossett, J. L., \& Williams, J. (1998). Perceived discrimination among women in law enforcement. Women and Criminal Justice, 10(1), 53-73. https://doi.org/10.1300/J012v10n01 03

Henning, E., Van Rensburg, W. \& Smit, B. (2004). Finding your way in qualitative research. Pretoria, Gauteng province, South Africa: Van Schaik.

Henning, E., Van Rensburg, W., \& Smit, B. (2004). Finding your way in qualitative research. Pretoria: van Schaik.

Hlongwane, B. (2016). Interview, Bernard Hlongwane by author Victory Park. Johannesburg, 20 October 2016.

Hoobler, M. J., Lemmon, G., \& Wayne, S. J. (2016). Women's Managerial Aspirations: An Organizational Development Perspective. Journal of Management, 1-28.

Huhman, H. R. (2016). STEM fields and the gender gap: where are the women? New York: Forbes. Available from http://www.forbes.com/sites/work-inprogress/2012/06/20/ stem-fields-and-the-gender-gap-where-are-thewomen/\#2ead5b3b33a9 [Accessed 10/10/2020]

Khan S., Lootvoet, B., \& Mantzaris, E. (2006) the clash between traditional \& modern systems of governance in the Durban metropolis-A tale of two administrative civilizations. University of Kwazulu Natal.

Kurtz, D. L., Linnemann, T., \& Williams, L. S. (2012). Reinventing the matron: The continued importance of gendered images and the division of labor in modern policing. Women and Criminal Justice, 22(3), 239-263. https://doi.org/10.1080/08974454.2012.687966

Kurtz, D. L., Linnemann, T., \& Williams, L. S. (2012). Reinventing the matron: The continued importance of gendered images and division of labor in modern policing. Women \& Criminal Justice, 22(3), 239-263. https://doi.org/10.1080/08974454.2012.687966

Leedy P.D. \& Ormrod J.E. 2005: Practical research: planning and design. New York: Pearson Merrill Prentice Hall.

Lewis, G. Palacious, S. \& Valenzuela, M.A. 2016. An integration framework of organisational moral Development, legitimacy and corporate responsibility. Business and Society Review. Volume 121-4. https://doi.org/10.1111/basr.12104

McDowell, L. (2016). Capital Culture: Gender at work in the city, Wiley online Library Pathak, A. A., \& Purkayastha, A. (2016). More women on Indian boards: Moving beyond mere regulations and tokenism. Strategic Direction, 32(3), 13-15. https://doi.org/10.1108/SD-05-2015-0081

Mello D.M. and Phago K. 2007: Affirming women in managerial positions in the South African Public Service. Politeia. 26(2), 145-158.

Mlotshwa (2017). Interview, Fikile Mlotshwa by author. Victory Park. Johannesburg. January 2017.

Morash, M., \& R. Haar. (1995). Gender, Workplace Problems, and Stress in Policing. Justice Quarterly, 12, 113-136. https://doi.org/10.1080/07418829500092591

National Planning Commission. 2010. National Development plan 2030: Our future-make it work. Available from: https://www.poa.gov.za/news/Documents/NPC\%20National \%20Development $\% 20$ Plan\%20Vision $\% 202030 \% 20$-lores.pdf [Accessed on 2021-03-21]

Newham, G., Masuku, T., \& Dlamini, J. (2006). Diversity and transformation in the South African Police Service: A study of police perspectives on race, gender and the community in 
the Johannesburg policing area. Research report written for the Centre for the Study of Violence and Reconciliation. Braamfontein, South Africa.

Palmer, I. (1991). Gender and population in the adjustment of African Economics: Planning for change. Geneva International Labour Organisation. Available from: women in development 1991.pdf (un.org) [Accessed on 22/10/2020].

Pandor. N. (2005). Minister of Education introducing the debate on the education budget, vote 15. National Assembly. Cape Town, South Africa

Payne, G., \& Payne, J. (2015). Key Concepts in Social Research. London: SAGE Publications.

Percy-Smith, J. (ed.). (2000). Policy responses to social exclusion: Towards inclusion. Buckingham, United Kingdom: Open University Press.

Polisa (2016). Interview, Ambrose Polisa by author. Orlando West, Johannesburg. September 2016.

Promotion of Equality and Prevention of Unfair Discrimination (PEPUDA) (Act 4 of 2000) of the Republic of South Africa. Pretoria: Government Printers.

Resnik, D.B. (2011). What is ethics in research \& why is it important. Retrieved from http://www.niehs.nih.gov/research/resources/ bioethics/whatis/ [Accessed 2018-11-29]

Rishani, M., Mallah, M., Houssami, S., \& Ismail, H. (2015). Lebanese perceptions of the glass ceiling. Equality, Diversity and Inclusion: An International Journal, 34(8), 678- 691. https://doi.org/10.1108/EDI-11-2014-0082

Ryan, G.W. \& Bernard, H.R. (2000). Data management and analysis methods. In Denzin, N.K. \& Lincoln, Y.S. (eds.) 2000. Handbook of qualitative research. 2nd edition. Thousand Oaks, California, United States of America: Sage Publications.

Saldana, J. [s.a.] An introduction to codes and coding. Available from: http://www.sagepub.com/sites/default/files/upmbinaries/24614_01_Saldana_Ch_01.pdf [Accessed: 2021-0305].

Schwanke, D. (2013). Barriers for Women to Positions of Power: How Societal and Corporate Structures, Perceptions of Leadership and Discrimination Restrict Women's Advancement to Authority. Earth Common Journal, 3(2). https://doi.org/10.31542/j.ecj.125

Shields, D., Funk, C. D., \& Bredemeier, B. (2016). The moral frameworks and foundations of contesting orientations. Journal of Psychology, 38, 117-127. https://doi.org/10.1123/jsep.2015-0139

Shore, L. M., Randel, A. E., Chung, B. G., Dean, M. A., Ehrhart, K. H., \& Singh, G. (2011). Inclusion and Diversity in Work Groups. A Review and Model for Future Research, 37(4). https://doi.org/10.1177/0149206310385943
Shore, L.M., Randel, A.E., Chung, B.G., Dean, M.A., Ehrhart, K.H. \& Singh, G. 2011. Inclusion and diversity in work groups: A review and model for future research. Journal of Management, 37(4):1262-1289. https://doi.org/10.1177/0149206310385943

Singh, Val. (2007). Women and the Glass Ceiling. The Effective Executive.

Somvadee, C., \& Morash, M. (2008). Dynamics of sexual harassment for police women working alongside men. Policing: An International Journal of Police Strategies and Management, 31(3), 485-498. https://doi.org/10.1108/13639510810895821

South African History Online (SAHO). 2017. Sophia Theresa Williams de Bruyn. Available from: http://www.sahistory.org. za/people/sophia-theresa-williamsde-bruyn [Accessed: 02/10/2020].

South African history online. (2017). Sophia Theresa Williams de Bruyn. Retrieved from http://www.sahistory.org.za [Accessed on 2019-05-02]

South African Police Service. (2002). Address by the National Commissioner of the South African Police Service: Celebration of Women's Day. 6 August 2002. Pretoria. Retrieved from: http://www.saps.org.za. [Accessed 2019-0501]

Statistics South Africa (2017). Estimates of National Expenditure 2017. National Treasury: Pretoria. Republic of South Africa.

Statistics South Africa. 2015. The status of women in the South African Economy. Available from: http://www.statssa.gov.za/? $\mathrm{p}=11375$ Accessed on 24 March 2021

UNDP. (2015). "Promote gender equality and empower women". Pretoria: Statistics South Africa.

United Sates Glass Ceiling Commission (1995). A Solid Investment: Making Full Use of the Nation's Human Capital (Final Report of the Commission). Washington, DC: U.S. Government Printing Office.

University of South Africa. (2016). Policy on Research Ethics. Available from: https://www.unisa.ac.za/static/corporate_web/ Content/Colleges/CLAW/Research/Doc [Accessed on 202103-21]

Van der Berg, S. (2014). "Inequality, poverty and prospects for redistribution." Development Southern Africa 31(2). https://doi.org/10.1080/0376835X.2013.871196

Van Kessel, I. (2001). Transforming the South African Police Service (SAPS): The changing meaning of change. Paper delivered at the South African Sociological Association congress, 1-4 July 2001.

Watson, K. (1999). Gender bias, the struggle to establish a permanent women police presence in South Africa during the Union period: 1915-1960. Journal for contemporary history, $24(1), 1-14$.

\section{https://doi.org/10.6000/1929-4409.2021.10.153}

(C) 2021 Dee Khosa; Licensee Lifescience Global.

This is an open access article licensed under the terms of the Creative Commons Attribution Non-Commercial License (http://creativecommons.org/licenses/by-nc/3.0/) which permits unrestricted, non-commercial use, distribution and reproduction in any medium, provided the work is properly cited. 